ANADOLU, J. of AARI

ISSN: $1300-0225$ (Print)

E-ISSN: 2667-6087 (Online)

2021, $31(1): 1-8$

DOI: $10.18615 /$ anadolu.949814

\title{
A Preliminary Study on the Response of Confectionery Sunflower (Helianthus annuus L.) to Arbuscular Mycorrhizal Fungi (AMF)
}

\author{
Filiz PARÇA \\ Aydin UNAY ${ }^{2}$ \\ ${ }^{1}$ Aydın Adnan Menderes Uni. Institute of Natural and Applied Sci. Aydın/TURKEY \\ ${ }^{2}$ Aydın Adnan Menderes Uni. Agricultural Fac., Field Crop Dep., Aydın/TURKEY \\ ${ }^{l}$ https://orcid.org/0000-0003-2396-9327 $\quad{ }^{2}$ https://orcid.org/0000-0002-7278-4428 \\ "Corresponding author's (Sorumlu yazar)e-mail: aunay@adu.edu.tr \\ Received (Geliş tarihi): 18.06.2020ａccepted (Kabul tarihi): 10.09.2020
}

\begin{abstract}
This preliminary study was carried out to investigate the effect of arbuscular mycorrhizal fungi (AMF) on yield, seed characters and chlorophyll content of confectionery sunflower (Helianthus annuus L.). The experiment was conducted at Tavas/Denizli in the 2018 growing season. The experimental design was "Randomized Complete Block Design $(R C B D)$ " with four replications. Seed coating and soil spraying of AMF applications were compared with control (non-treatment $A M F)$. The differences among treatments were significant for plant height ( $\mathrm{cm})$, head diameter $(\mathrm{cm})$, seed width (mm), single plant yield $(\mathrm{g})$, thousand kernel weight $(\mathrm{g})$, yield $\left(\mathrm{kg} \mathrm{ha}^{-1}\right)$, chlorophyll content index (CCI) and soil plant analysis development (SPAD) values. The seed coating had significant and higher values for plant height $(\mathrm{cm})$, head diameter (cm), seed width (mm), single plant yield (g), thousand kernel weight $(\mathrm{g})$, yield $\left(\mathrm{kg} \mathrm{ha}^{-1}\right)$, chlorophyll content index (CCI) and SPAD values, whereas hull ratio was found to be similar between AMF applications and control. It was concluded that seed coating with AMF can be profitable for confectionery sunflower producers due to increased yield and low cost. The results of this preliminary study should be supported by findings from multiple locations and years.
\end{abstract}

Keywords: Confectionary sunflower, Helianthus annuus L., arbuscular mycorrhiza, yield, hull ratio, chlorophyll content.

\section{Çerezlik Ayçiçeğinin (Helianthus annuus L.) Arbusküler Mikorhizal Fungus (AMF)’lara Tepkisi Üzerine Bir Ön Çalışma}

ÖZ: Bu ön çalışma, çerezlik ayçiçeğinde (Helianthus annuus L.) arbüsküler mikorizal fungus (AMF)'un verim, dane özellikleri ve klorofil içeriği üzerine etkisini belirlemek amacıyla yapılmıştır. Deneme 2018 yılında Tavas/Denizli bölgesinde yürütülmüs ve 4 tekerrürlü Tesadüf Blokları Deneme Desenine göre planlanmıştır. AMF'nin tohum kaplama ve üst uygulamaları

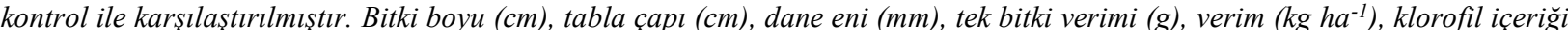
ve SPAD değerleri yönünden uygulamalar arası farklılıkların önemli olduğu saptanmıştır. Tohum kaplama uygulamasının bitki boyu (cm), tabla çapı (cm), dane eni (mm), tek bitki verimi (g), verim $\left(\mathrm{kg} \mathrm{ha}^{-1}\right)$, klorofil içeriği ve SPAD değerleri yönünden önemli düzeyde daha yüksek değerlere sahip olduğu buna karşın kabuk oranının uygulamalar arasında benzer olduğu belirlenmiştir. Sonuçta, tohum kaplaması şeklinde AMF uygulamasının verim artışı ve düşük maliyeti nedeniyle üreticiler için karlı olabileceği kanısına varılmıştır. Bir ön çalışma niteliğinde olan bu araştırma sonuçlarının birden fazla çevrede ve yılda yürütülen çalışma bulguları ile desteklenmesinde yarar vardır.

Anahtar Kelimeler: Çerezlik ayçiçeği, Helianthus annuus L. arbüsküler mikoriza, verim, kabuk oranı, klorofil içeriği. 


\section{INTRODUCTION}

The interest in confectionery sunflower is increasing worldwide. The proportion of confectionery sunflower in the world and Turkey are $2.6 \%$ and $8.37 \%$ of total sunflower production, respectively (Anonymous, 2018). In our country, the planting area of confectionery sunflower reached 105 thousand hectares. Central Anatolia (Ankara, Kayseri and Kırkkale) and Aegean Regions (Denizli) are the main production areas of confectionary sunflower.

Confectionery sunflower was defined as black white, black with stripes, high hull percentage and larger than the oil type seeds (Hladni et al., 2012). It was emphasized that there is no certified seed and not many registered hybrids in confectionery sunflower production (Pekcan et al., 2015). Similarly, many landraces with different grain colors and characteristics are grown for confectionery sunflower production (Tan et al., 2017; Tan and Kaya, 2019). Also, confectionery sunflower cultivation as monoculture negatively affected crop productivity and quality depending on plant nutrient problems.

Arbuscular mycorrhizal fungi (AMF) are cited as a promising option for sustainable agriculture (Rillig et al., 2016; Thirkell et al., 2017). With the symbiotic relationship between AMF and the crop, the plant supplies a source of carbon to fungi, while the fungi is responsible for the acquisition of immobile nutrients including macro and micronutrients beyond the range of plant's roots via their hyphae. (Bago et al., 2000; Govindarajulu et al., 2005; Jiang et al., 2017; Smith and Read, 2008). It was revealed that AMF is the most common type of useful microbial community in the soil (Heidari and Karami, 2014; Ibrahim, 2018). Mycorrhizal fungi induce plant growth through increasing the availability of mineral nutrients such as $\mathrm{P}, \mathrm{Zn}$ and $\mathrm{Cu}$ (Phiri et al., 2003). Inoculation of roots with AMF can also reduce the harmful effects of chemical fertilizer used in conventional farming (Silva et al., 2015), increase plant defense mechanisms to alleviate different stresses (Mayer et al., 2017) and aid in weed control (Veiga et al., 2011). In addition, colonization of arbuscular mycorrhiza (AM) in the rhizosphere enhances growth (Jalaluddin and Hamid, 2011; Silva et al., 2015) and morphological parameters (Kavitha and Nelson, 2014) in sunflower. AMF applications increased head diameter, seed number in head, seed and oil yield and oil percentage when compared with nontreatment (control) (Soleimanzadeh, 2010).

In addition to increases in yield, yield components and seed quality, the percentage of $\mathrm{N}$ in leaves and seeds is enhanced by mycorrhizal fungi in sunflower (Gholamhoseini et al., 2013). It was emphasized that the SPAD (soil plant analysis development) value of plant leaves reflected tissue nitrogen levels, and that the higher SPAD indices in plants with AMF were positively correlated with a higher photosynthetic potential due to better nutrient status (Chang and Robison, 2003; Campanelli et al., 2012). Seed coating is shown to be the most effective method for the application of exogenous AMF for many crops such as wheat, maize and cowpea (Oliveira et al., 2016; Ma et al., 2019) although the lack of cost-effective methods restricts the application of AMF (Vosátka et al., 2012; O'Callaghan, 2016) in field conditions.

Many previous studies were pot studies under greenhouse conditions. Our study is the first conducted under actual field conditions and aimed at producer practices in confectionery sunflower. Therefore, we focused on evaluating the effectiveness of AMF on yield, yield components and chlorophyll content of confectionery sunflower under field conditions.

\section{MATERIALS and METHODS}

This study was carried out in a farmer's field (Tavas/Denizli; $37^{\circ} 49^{\prime}$ N $28^{\circ} 95^{\prime}$ E) that was used to grow monocrop confectionary sunflower in recent years. Previous seasons were most damaged by mildew disease. The experiment was arranged in a Randomized Complete Block Design with four replications in 2018. The soil of the experimental area was defined as clayey, slightly alkaline, poor organic matter, non-saline, high lime and 
insufficient nitrogen and phosphorus (Table 1). The province of Tavas/Denizli shows a transition climate between the Mediterranean and Aegean regions with hot, dry summers and cold/mild, rainy winters. When the climate data of the 2018 sunflower growing season were evaluated, the mean temperatures of July and August and precipitation of May had the highest values (Table 2).

\section{Mycorrhiza applications}

The local cultivar of confectionery sunflower (Helianthus annuus L.) İnegöl Alası was used as material. To inoculate seeds with mycorrhiza, 2.0 $\mathrm{kg}$ of seeds was treated with $25 \mathrm{~g}$ mycorrhiza mixture and $0.5 \mathrm{lt}$ distilled water, then the seeds were aerated to reduce moisture to $10 \%$. The dosage and method of application were as recommended in the company's license (Anonymous, 2020). The list of fungi contents in the product are given in Table 3.

As a second application method, mycorrhiza was applied by soil spraying before first irrigation at the 6-8 leaf stage. To water one plant, $260 \mathrm{~cm}^{3}$ of the suspension was used, which corresponds to a dose of $8.75 \mathrm{mg}$ of the preparation per plant (Mikiciuk et al., 2019).

\section{Cultural management}

Two hours after inoculation, seeds were sown by pneumatic drill machine. Sowing norm was $0.7 \mathrm{~m}$ x $0.25 \mathrm{~m}$ in plots of ten rows measuring $7 \mathrm{~m} \mathrm{x} 7 \mathrm{~m}$. Plots were fertilized with $40 \mathrm{~kg} \mathrm{ha}^{-1} \mathrm{~N}, 70 \mathrm{~kg} \mathrm{ha}^{-1}$ $\mathrm{P}_{2} \mathrm{O}_{5}$ and $35 \mathrm{~kg} \mathrm{ha}^{-1} \mathrm{~K}_{2} \mathrm{O}$ before planting, and 120 $\mathrm{kg} \mathrm{ha}^{-1} \mathrm{~N}$ was applied before first irrigation. Drip irrigation was applied three times. The experimental area was hoed twice for thinning at the early seedling stage and weeding at the 3-4 leaf stage. No plants showing symptoms of disease were encountered during the experimental period although downy mildew is one of the most devastating diseases for confectionery sunflower in this region. Also, there was no need to control broomrape as the critical level was not exceeded.

\section{Measurements}

\section{Chlorophyll content and SPAD}

The relative chlorophyll content (CCI; chlorophyll content index) was measured twice by two leafclip chlorophyll meters, the CCM-200 Plus (Apogee) and SPAD-502 meter (Konica Minolta) at the stages of flowering (DAS 74 days) and seed development (DAS 90 days) according to the method suggested by Gornik (2011).

Table 1. Soil analysis of experimental area ${ }^{\S}$

Çizelge 1. Deneme alanının toprak analiz sonuçları ${ }^{\S}$.

\begin{tabular}{lccccccc}
$\begin{array}{l}\text { Soil structure } \\
\text { Toprak yapis1 }\end{array}$ & $\mathrm{pH}$ & $\begin{array}{l}\text { Lime (\%) } \\
\text { Kireç (\%) }\end{array}$ & $\begin{array}{l}\text { Organic matter (\%) } \\
\text { Organik madde (\%) }\end{array}$ & $\begin{array}{l}\text { Total salt (\%) } \\
\text { Toplam tuz (\%) }\end{array}$ & $\begin{array}{l}\mathrm{N} \\
(\%)\end{array}$ & $\begin{array}{l}\mathrm{P}_{2} \mathrm{O}_{5} \\
\left(\mathrm{~kg} \mathrm{ha}^{-1}\right)\end{array}$ & $\begin{array}{l}\mathrm{K}_{2} \mathrm{O} \\
\left(\mathrm{kg} \mathrm{ha}^{-1}\right)\end{array}$ \\
\hline Clayey/Killi & 8.0 & 28.4 & 1.28 & 0.01 & 0.09 & 42.6 & 988.0 \\
\hline
\end{tabular}

$\S$ Soil Analysis Laboratory of Aydın Adnan Menderes University, Faculty of Agriculture.

$\S$ Aydın Adnan Menderes Üniversitesi, Ziraat Fakültesi Toprak Analiz Laboratuvarı.

Table 2. Monthly mean temperature, moisture and total monthly precipitation for 2018 (Anonim, 2018).

Çizelge 2. 2018 yılına ait ortalama sıcaklıklar, nem ve aylık yağış miktarı (Anonim, 2018).

\begin{tabular}{lccc}
$\begin{array}{l}\text { Months } \\
\text { Aylar }\end{array}$ & $\begin{array}{c}\text { Mean temp. } \\
\text { Ort. sic. } \\
\left({ }^{\circ} \mathrm{C}\right)\end{array}$ & $\begin{array}{c}\text { Moisture } \\
\text { Nem } \\
(\%)\end{array}$ & $\begin{array}{c}\text { Precipitation } \\
\text { Yağ/ş } \\
(\mathrm{mm})\end{array}$ \\
\hline April/Nisan & 12.5 & 55.1 & 17.8 \\
May/Mayıs & 14.9 & 65.6 & 90.5 \\
June/Haziran & 18.3 & 61.9 & 39.1 \\
July/Temmuz & 22.3 & 49.7 & 29.5 \\
August/Ağustos & 22.6 & 51.8 & 20.1 \\
September/Eylül & 19.3 & 47.7 & 4.1 \\
\hline
\end{tabular}


Table 3. Contents of biological (microbial) material used in the study.

Çizelge 3. Çalışmada kullanılan biyolojik (mikrobiyal) materyalin içeriği.

\begin{tabular}{cclcc}
\hline & $\begin{array}{c}\text { Live organisms name } \\
\text { Canlı organizma adi }\end{array}$ & $\begin{array}{c}\text { Number of live organisms } \\
\text { Canlı organizma sayıs } \\
\left.\text { (propagule } \mathrm{g}^{-1}\right)\end{array}$ & $\mathrm{pH}$ \\
\hline Glomus mosseae & Glomus etunicatum & $\begin{array}{l}\text { Glomus } \\
\text { intraradices }\end{array}$ & $1 \times 10^{5}$ & $7-9$ \\
\hline
\end{tabular}

\section{Yield and yield components}

In the harvest stage, the five middle rows were used for yield estimation $\left(\mathrm{kg} \mathrm{ha}{ }^{-1}\right)$ at $10 \%$ humidity. Plant height $(\mathrm{cm})$, head diameter $(\mathrm{cm})$ and single plant yield $(\mathrm{g})$ were measured in 10 randomly selected plants at the R9 stage (bracts yellow and brown, plant at physiological maturity) as defined by Schneiter and Miller (1981).

\section{Kernel characteristics}

Seed length $(\mathrm{mm})$ and seed width $(\mathrm{mm})$ was measured using a vernier caliper (Hladni et al., 2016). Hull ratio (\%) was calculated according to the formula suggested by Baldini and Vannozzi (1996) mass of hulls removed during dehulling/mass of seed sample before dehulling at $10 \%$ moisture in laboratory. Four replicated 100seed lots from the dried and cleaned seed samples from each parcel after harvest were weighed and averaged to determine thousand kernel weight (g) at $10 \%$ moisture.

\section{Statistical analysis}

Experimental data from seed coating, soil spraying and control were subjected to variance analysis with TARIST Statistical Package Program (Acikgoz et al., 1994) in accordance with the randomized block experimental design. The differences between means were compared using LSD (Steel and Torrie, 1980).

\section{RESULTS and DISCUSSION}

\section{Grain yield}

The grain yield of confectionery sunflower was significantly affected by AMF inoculation (Table 4). In addition, the differences among treatments were significant for single plant yield $(\mathrm{g})$ and yield $\left(\mathrm{kg} \mathrm{ha}^{-1}\right)$. Single plant yield values were $98.0 \mathrm{~g}$ for seed coating and $89.50 \mathrm{~g}$ for soil spraying compared with control $(82.50 \mathrm{~g})$. Similarly, yield per hectare was significantly higher in the seed coating of AMF $(3430.0 \mathrm{~kg})$ followed by soil spraying $(3132.5 \mathrm{~kg})$. Compared to the control, the yield increases with seed coating and soil spraying of AMF were $18.78 \%$ and $8.48 \%$ (542 $\mathrm{kg} \mathrm{ha}^{-1}$ and $\left.245 \mathrm{~kg} \mathrm{ha}^{-1}\right)$, respectively. Similar findings were earlier reported by Chandrashekara et al. (1995), Soleimanzadeh (2010), Heidari and Karami (2014), Chaghamarani et al. (2019) and Kalaiyarasan et al. (2019) in sunflower.

\section{Yield components}

Plant height and head diameter are two important yield components positively correlated with yield (Kholghi et al., 2011; Sincık and Goksoy, 2014). Table 4 shows that the differences among treatments (two mycorrhiza applications and control) were significant for plant height and head diameter. Seed coating with AMF produced significantly taller plants $(245.75 \mathrm{~cm})$ and increased head diameter $(29.48 \mathrm{~cm})$ than those of the soil spraying $(202.50 ; 26.98 \mathrm{~cm})$ and noninoculated treatments $(189.75 \mathrm{~cm} ; 23.70 \mathrm{~cm})$. Similarly, other studies revealed positive effects of AMF on plant height and head diameter (Soleimanzadeh, 2010; Kavitha and Nelson, 2014; Ibrahim, 2018; Kalaiyerasan et al., 2019).

\section{Kernel characteristics}

The characteristics of confectionery sunflower for market value are: thousand kernel weight, hull/kernel ratio and seed size (Hladni et al., 2016). The treatments with AMF produced a significant increase in thousand kernel weight and seed width in comparison with control (Table 5). Seed weight values of seed coating and soil spraying were 8.60 and $8.53 \mathrm{~mm}$, respectively, compared with control $(6.40 \mathrm{~mm})$. Similarly, the effects of AMF on seed 
length and hull ratio were positive. It can be said that increases in seed length, width and hull ratio were reflected in thousand kernel weight. Compared to control, the increase in thousand kernel weight due to AMF varied between $16.94 \%$ and 38.54\%. Soleimanzadeh (2010) and Kalaiyerasan et al. (2019) found that the effect of AMF on thousand kernel weight was positive. Also, it was clearly seen that both AMF applications increased hull ratio.

\section{Chlorophyll content}

Significant differences were determined among mycorrhizal treatments and control for SPAD and
$\mathrm{CCI}$ at the flowering and seed development stages (DAS: 74 and 90). Three LSD groups were formed for all four parameters (Table 6). The effect of seed coating was better than soil spraying and control for SPAD and CCI values. Also, SPAD and CCI values were in parallel with each other. When the results were compared with the findings of Chang and Robison (2003) for hardwood, Campanelli et al. (2012) for globe artichoke, Glolamhoseini et al. (2013) for sunflower, Makarian et al. (2016) for maize and Fileccia et al. (2017) for durum wheat, they confirmed an increase in chlorophyll content by AMF application due to the increase in plant nitrogen status.

Table 4. Mean values of plant height (PH), head diameter (HD), single plant yield (SPY) and yield ( $\left.\mathrm{kg} \mathrm{ha}^{-1}\right)$.

Çizelge 4. Bitki boyu (BB), tabla çapı (TÇ), tek bitki verimi (TBV) ve verim $\left(\mathrm{kg} \mathrm{ha}^{-1}\right)$ 'e ilişkin ortalama değerler.

\begin{tabular}{lcccc} 
Applications & $\mathrm{PH}^{*}$ & $\mathrm{HD}^{*}$ & $\mathrm{SPY}^{*}$ & Yield $^{*}$ \\
Uygulamalar & $\mathrm{BB}(\mathrm{cm})$ & $\begin{array}{c}\mathrm{TC} \\
(\mathrm{cm})\end{array}$ & $\begin{array}{c}\mathrm{TBV} \\
(\mathrm{g})\end{array}$ & $\begin{array}{c}\text { Verim } \\
\left(\mathrm{kg} \mathrm{ha}^{-1}\right)\end{array}$ \\
\hline Seed coating / Tohum kaplama & & $29.48 \mathrm{a}$ & $98.00 \mathrm{a}$ & $3430.0 \mathrm{a}$ \\
Soil spraying/ Toprağa püskürtme & $245.75 \mathrm{a}$ & $26.98 \mathrm{~b}$ & $89.50 \mathrm{~b}$ & $3132.5 \mathrm{~b}$ \\
Control/ Kontrol & $202.50 \mathrm{~b}$ & $23.70 \mathrm{c}$ & $82.50 \mathrm{c}$ & $2887.5 \mathrm{c}$ \\
LSD $(\alpha: 0.05)$ & $189.75 \mathrm{c}$ & 2.47 & 3.21 & 112.3 \\
CV $(\%)$ & 11.49 & 5.4 & 14.24 & 2.16 \\
\hline
\end{tabular}

*Same letters in a column are not significantly different at the 0.05 probability level.

*Aynı harfle gösterilen ortalamalar arasinda önemli fark $(P \geq 0,05)$ yoktur.

Table 5. Mean values of seed length (SL), seed width (SW), thousand kernel weight (TKW) and hull ratio (HR).

Çizelge 5. Tane boyu (DB), tane eni (DE), bin tane ağırlı̆̆ (BDA) ve kabuk oranı (KO) özelliklerine ilişkin ortalama değerler.

\begin{tabular}{lcccc} 
Applications & SL & $\mathrm{SW}^{*}$ & $\mathrm{TKW}^{*}$ & HR \\
Uygulamalar & TB & TE & BTA & $\begin{array}{c}\text { KO } \\
(\%)\end{array}$ \\
\hline Seed coating / Tohum kaplama & $(\mathrm{mm})$ & $(\mathrm{mm})$ & $146.81 \mathrm{a}$ & 47.59 \\
Soil spraying/ Toprağa püskürtme & 19.27 & $8.60 \mathrm{a}$ & $123.92 \mathrm{~b}$ & 46.85 \\
Control / Kontrol & 17.60 & $6.40 \mathrm{~b}$ & $105.97 \mathrm{c}$ & 42.38 \\
\hline LSD $(\alpha: 0.05)$ & 17.36 & 1.33 & 9.99 & \\
CV $(\%)$ & & 10.97 & 14.60 & 10.20 \\
\hline
\end{tabular}

"Same letters in a column are not significantly different at the 0.05 probability level.

*Aynı harfle gösterilen ortalamalar arasında önemli fark $(P \geq 0,05)$ yoktur.

Table 6. Mean values of SPAD (soil plant analysis development) and CCI (chlorophyll content index) at two different growing stages (1; flowering stage and 2; seed development).

Çizelge 6. İki farklı büyüme döneminde (1; çiçeklenme dönemi ve 2 ; tane gelişimi) SPAD ve klorofil içeriğine (CCI) ilişkin ortalama değerler.

\begin{tabular}{lcccc}
\hline $\begin{array}{l}\text { Applications } \\
\text { Uygulamalar }\end{array}$ & ${\text { SPAD } 1^{*}}^{*}$ & SPAD $2^{*}$ & CCI $1^{*}$ & ${\text { CCI } 2^{*}}^{*}$ \\
\hline Seed coating / Tohum kaplama & $72.37 \mathrm{a}$ & $70.92 \mathrm{a}$ & $33.23 \mathrm{a}$ & $31.81 \mathrm{a}$ \\
Soil spraying / Toprağa püskürtme & $53.12 \mathrm{~b}$ & $53.87 \mathrm{~b}$ & $26.00 \mathrm{~b}$ & $25.94 \mathrm{~b}$ \\
Control / Kontrol & $40.99 \mathrm{c}$ & $42.18 \mathrm{c}$ & $20.43 \mathrm{c}$ & $20.80 \mathrm{c}$ \\
\hline LSD $(\alpha: 0.05)$ & 0.83 & 1.35 & 0.62 & 0.81 \\
CV $(\%)$ & 0.95 & 1.47 & 1.38 & 1.87 \\
\hline
\end{tabular}

*Same letters in a column are not significantly different at the 0.05 probability level.

*Aynı harfle gösterilen ortalamalar arasında önemli fark $(\mathrm{P} \geq 0,05)$ yoktur. 


\section{CONCLUSIONS}

Summarizing the main results, seed coating treatment may have important potential to promote confectionery sunflower production with increases in seed yield under field condition. Also, seed coating should be considered an efficient and easy method of AMF inoculation for crops. In addition, AMF application increased yield by $550 \mathrm{~kg} \mathrm{ha}^{-1}$ with a cost of $500 \mathrm{TL}$ compared to the control. The sales price of confectionery sunflower for 2018 was $5000 \mathrm{TL} \mathrm{ton}^{-1}$, therefore, the net return can be estimated as $2250 \mathrm{TL} \mathrm{ha}{ }^{-1}$. This finding indicated

\section{REFERENCES}

Acikgoz, N., M. E. Akkas, A. Moughaddam, and K. Ozcan. 1994. TARIST: Statistics and quantitative genetic Package for pc's. Center of Computer Research and Practice. Proceedings of the International Symposium of Computer, October 5-7, 1994, University of Ege, Izmir, Turkey.

Anonim, 2018. Denizli ili 2018 yılı iklim verileri. Meteoroloji Genel Müdürlüğü. https://www.mgm.gov.tr/

Anonymous, 2018. Turkey Statistical Institute. www.tuik.gov.tr. [Date of access; 14.10.2018].

Anonymous, 2020. Application Guide of Shubhodaya Mycorrhizal Fertilizer. www.mikorizalgubre.com uygulama-yontemi. [Date of access; 09.09.2020].

Bago, B., P.E. Pfeffer, and Y. Shachar-Hill. 2000. Carbon metabolism and transport in arbuscular mycorrhizas. Plant Physiology 124: 949-957.

Baldini, M., and G.P. Vannozzi. 1996. Yield relationships under drought in sunflower genotypes obtained from a wild population and cultivated sunflowers in rain-out shelter in large pots and field experiments. Helia 22: 81-96.

Campanellii, A., C. Ruta, A. Tagarelli, I. Morone-Fortunato, and G. De Mastro. 2012. Effectiveness of mycorrhizal fungi on globe artichoke (Cynara cardunculus L. var. scolymus) micropropagation. Journal of Plant Interactions. 9 (1): 100-106.

Chaghamarani, N., G.H.R. Mohammadi, and M. Ghobadi. 2019. Yield and growth characteristics of sunflower cultivars inoculated by arbuscular mycorrhizal fungi under drought tension conditions. Crop Physiology (Iran) 10 (4): 75-92.

Chandrashekara, C.P., V.C. Patil, and M.N. Sreenivasa. 1995. VA-mycorrhiza mediated $\mathrm{P}$ effect on growth and yield of sunflower (Helianthus annuus L.) at different $\mathrm{P}$ levels. Plant and Soil. 176: 325-328. that seed coating with AMF can result in sustainable confectionery sunflower cultivation for the farmer despite the inoculation costs. It is recommended that further research is needed to support the results of this preliminary study.

\section{ACKNOWLEDGEMENTS}

This research article is part of the master thesis conducted by Filiz PARÇA at Aydın Adnan Menderes University, Institute of Natural and Applied Science, Field Crops Department.

Chang, S.X, and D.J. Robison. 2003. Nondestructive and rapid estimation of hardwood foliar nitrogen status using the SPAD-502 chlorophyll meter. Forest Ecology and Management 181: 331-338.

Fileccia,V., P. Ruisi, R. Ingraffia, D. Giambalvo, A. Salvatore Frenda, and F. Martinelli. 2017. Arbuscular mycorrhizal symbiosis mitigates the negative effects of salinity on durum wheat. PLoS One. 12 (9): e0184158. https://doi.org/10.1371/journal.pone.0184158.

Gholamhoseini, M. A. Ghalavand, A. Dolatabadian, E. Jamshidi, and A. Khodaei-Joghan. 2013. Effects of arbuscular mycorrhizal inoculation on growth, yield, nutrient uptake and irrigation water productivity of sunflowers grown under drought stress. Agricultural Water Management 117: 106-114.

Gornik, K. 2011. The effect of temperature treatments during 'Wielkopolski' sunflower seed imbibition and storage on plant tolerance to chilling. Folia Horticulture. 23(1):83-88.

Govindarajulu, M., P.E. Pfeffer, H.R. Jin, J. Abubaker, D.D. Douds, J.W. Allen, H. Bucking, P.J. Lammers, and Y. Shachar-Hill. 2005. Nitrogen transfer in the arbuscular mycorrhizal symbiosis. Nature 435: 819-823.

Heidari, M., and V. Karami. 2014. Effects of different mycorrhiza species on grain yield, nutrient uptake and oil content of sunflower under water stress. Journal of the Saudi Society of Agricultural Sciences. 13 (1): 9-13.

Hladni, N., V. Miklič, S. Jocić, M. Jocković, I. Radeka, and N. Lečić. 2012. Determining the influence of yield components on the confectionary sunflower seed yield. pp. 55-62. In: Proceedings of 53rd Conference of Oil Industry. Production and Processing of Oilseeds, Herceg Novi, Montenegro.

Hladni, N., S. Jocic, V. Miklic, D. Miladinovic, and M. Zoric. 2016. Interrelationship between 1000 seed weight with other quantitative traits in confectionary sunflower. Ekin Journal of Crop Breeding and Genetics 2 (1): 51-56. 
Ibrahim, M. 2018. Response of seeds quality of sunflower to inoculation with single and mixed species of indigenous arbuscular mycorrhizal fungi. The Open Agriculture Journal. 12: 123-130.

Jalaluddin, M., and M. Hamid. 2011. Effect of adding inorganic organic and microbial fertilizers on seed germination and seedling growth of sunflower. Pakistan Journal of Botany 43: 2807-2809.

Jiang, Y., W. Wang, Q. Xie, N. Liu, L. Liu, D. Wang, X. Zhang, C. Yang, X. Chen, and D. Tang. 2017. Plants transfer lipids to sustain colonization by mutualistic mycorrhizal and parasitic fungi. Science 356: 1172.

Kalaiyarasan, C., M.V. Sriramachandrasekharan, S. Jawahar, K. Suseendran, R. Ramesh, S. Ramesh, and R. Kanagarajan. 2019. Growth and yield of sunflower as influenced by VAM and phosphorus application. Journal of Pharmacognosy and Photochemistry 8 (2): 836-839.

Kavitha, T., and R. Nelson. 2014. Effect of arbuscular mycorrhizal fungi (AMF) on growth and yield of sunflower (Helianthus annuus L.). Journal of Experimental Biology and Agricultural Sciences 2 (25): 226-232.

Kholghi, M., I. Bernousi, R. Darvishzadeh, A. Pirzad, and H. H. Maleki. 2011. Collection, evaluation and classification of Iranian confectionary sunflower (Helianthus annuus L.) populations using multivariate statistical techniques. African Journal of Biotechnology 10: 5444-5451.

Ma, Y., A. Látr, I. Rocha, H. Freitas, M. Vosátka, and R.S. Oliveira. 2019. Delivery of inoculum of Rhizophagus irregularis via seed coating in combination with Pseudomonas libanensis for cowpea production. Agronomy 9: 33.

Makarian, H., V. Poozesh, H.R. Asghari, and M. Nazari. 2016. Interaction effects of arbuscular mycorrhiza fungi and soil applied herbicides on plant growth Communications in Soil Science and Plant Analysis. DOI: 10.1080/00103624.2016.1146744

Mayer, Z., N.H. Duc, Z. Sasvari, and K. Posta. 2017. How arbuscular mycorrhizal fungi influence the defense system of sunflower during different abiotic stresses. Acta Biological Hungarian. 68 (4): 376-387.

Mikiciuk, G., L.Sas-Paszt, M. Mikiciuk, E. Derkowska, P. Trzcinski, S. Gluszek, A. Lisek, S. Wera-Bryl, and J. Rudnicka. 2019. Mycorrhizal frequency, physiological parameters, and yield of strawberry plants inoculated with endomycorrhizal fungi and rhizosphere bacteria. Mycorrhiza 29: 489-501.

O'Callaghan, M. 2016. Microbial inoculation of seed for improved crop performance: Issues and opportunities. Applied Microbiology and Biotechnology 100: 57295746.
Oliveira, R.S., I. Rocha, Y. Ma, M. Vosátka, and H. Freitas. 2016. Seed coating with arbuscular mycorrhizal fungi as an ecotechnological approach for sustainable agricultural production of common wheat (Triticum aestivum L.). Journal Toxicology Environmental Health Part A 79: 329-337.

Pekcan, V., G. Evci, I.M. Yilmaz, and Y. Kaya. 2015. Developing confectionery sunflower hybrids and determination of their yield performances in different environmental conditions. Ekin Journal of Crop Breeding and Genetics 1-2:47-55.

Phiri, S., I. M. Rao, E. Barrios, and B. R. Singh. 2003. Plant growth, mycorrhizal association, nutrient uptake and phosphorus dynamics in a volcanic-ash soil in Colombia as affected by the establishment of Tithonia diversifolia, Journal of Sustainable Agriculture 21 (3): 41-59.

Rillig M.C., M.A. Sosa-Hernandez, MA, J. Roy, C.A. AguilarTrigueros, K. Valyi, and A. Lehmann. 2016. Towards an integrated mycorrhizal technology: harnessing mycorrhiza for sustainable intensification in agriculture. Frontiers in Plant Science 7: 1-5.

Schneiter, A.A., and J.F. Miller. 1981. Description of sunflower growth stages. Crop Science 21: 901-903.

Silva, A.P.J., R.A. Silva, J.S. Santos, J.C.S. Medeiros, F.G. Carvalho, V. N. Silva, C.J. Oliceira, A.C. Araujo, L.E.S.F. Silva, and J.G. Junior. 2015. Soil chemical properties and growth of sunflower (Helianthus annuus L.) as affected by the application of organic fertilizers and inoculation with arbuscular mycorrhizal fungi. Revista Brasileira de Ciencia do Solo 39 (1): 151-161.

Sinc1k, M., and T. Goksoy. 2014. Investigation of correlation between traits and path analysis of confectionary sunflower genotypes. Notulae Botanicae Horti Agrobotanici 42 (1): 227-231.

Smith, S.E., and D.J. Read. 2008. Mycorrhizal symbiosis. San Diego, CA, USA: Academic Press.

Soleimanzadeh, H. 2010. Effect of VA-mycorrhiza on growth and yield of sunflower (Helianthus annuus L.) at different phosphorus levels. International Journal of Agricultural and Biosystems Engineering 4 (11): 820-823.

Steel, R. G. D., and J. H. Torrie. 1980. Principles and Procedures of Statistics. Second Ed. McGraw-Hill Book Company Inc., New York.

Tan, A.Ş., A.M. Altunok ve M. Aldemir. 2017. Bazı çerezlik ayçiçeği çeşit adaylarının Menemen, İzmir ekolojik koşullarında verim potansiyelleri. Anadolu, Ege Tarımsal Araştırma Enstitüsü Dergisi 27 (1): 1-16.

Tan, A.S., and Y. Kaya. 2019. Sunflower (Helianthus annuus L.) genetic resources, production and researches in Turkey. Oilseeds\&fats Crops and Lipids. (open access). https://www.ocl-journal.org/articles /ocl/ full_ html/ 2019/01/ocl190004s/ocl190004s.html. 
ANADOLU 31 (1) 2021

Thirkell, T.J, M.D. Charters, A.J. Elliott, S.M. Sait, and K.J. Field. 2017. Are mycorrhizal fungi our sustainable saviours? Considerations for achieving food security. Journal of Ecology 105: 921-929.

Veiga, R.S.L. J. Jansa, E. Frossard, and M.G.A. van der Heijden. 2011. Can arbuscular mycorrhizal fungi reduce the growth of agricultural weeds? PLoS ONE 6 : e27825.

Vosátka, M., A. Latr, S. Gianinazzi, and J. Albrechtova. 2012. Development of arbuscular mycorrhizal biotechnology and industry: Current achievements and bottlenecks. Symbiosis 58: 29-37. 